\title{
A VÁLLALATI COMPLIANCE ÉRTÉKELÉSE
}

A befektetốk, szabályozó hatóságok, a közvélemény és egyéb külsố érdekelt feleknek az átlátható múlködéshez kapcsolódó igényeire, elvárásaira adott újszerú válasz a compliance menedzsment, melynek célja a szabálytalan múködésból eredő kockázatok csökkentése. Az írás központi kérdése, hogy miként értékelhetố a compliance menedzsment tervezése, megvalósítása, mi tekinthetô elért eredménynek, és a megfelelés fejlesztése hogyan járul hozzá a vállalatok gazdasági hatékonyságához. A compliance menedzsment definícióját követốen az FSGO-iránymutatások, a SOX-törvény és a COSO-keretrendszer rövid ismertetése is olvasható. A vállalati önszabályozás három szakaszát lehet elkülöníteni, ezek mentén a compliance értékelés fókuszában a tervezési hatékonyság, a múködési hatékonyság és az eredmények mérése áll.

Kulcsszavak: compliance menedzsment, felelôs vállalatirányítás, kockázatkezelés, minôségmenedzsment, FSGO, SOX, COSO

Az utóbbi két évtizedben világszerte középpontba került a vállalati felelősségvállalás kérdése. Az Enron, a Parmalat, vagy Magyarországnál maradva a BKV-botrány és további gazdasági visszaélések nyomán a felelósségteljes vállalatvezetés mint elvárás jelent meg a társadalom és a befektetôk részéról. Másfelól nő a nyomás a törvényhozó és szabályozó hatóságok irányából, hiszen az elmúlt években egyre inkább felismerték, hogy a vállalati felelősség nem kizárólag, de jelentôsen a megfelelố belsô önszabályozáson múlik. A vállalatokra nehezedő nyomásból előny kovácsolható. Az elért eredményeket a piaci szereplő́k felé demonstrálva üzleti haszonra tehet szert bármely szervezet, amely kelló figyelmet és pénzt áldoz e területre. Így aztán számos vállalat pozitív tartalmú önkéntes beszámolókat tesz közzé az ügyfél-elégedettségi, környezetvédelmi vagy fenntartható fejlődést érintő kezdeményezéseiról (pl. munkaidő́n túli ügyfélszolgálati rendszer, szelektív hulladékgyújtés, papírmentes iroda stb.).

Kicsit mélyebbre ásva nyilvánvalóvá válik, hogy a vállalati botrányok, bizonyos termékek visszahívása vagy a márka értékvédelme sok szervezetet arra kényszerít, hogy felülvizsgálják a vállalati szintü felelősség, a kockázatértékelés és a minőségmenedzsment hagyományos technikáit a kutatás, fejlesztés, gyártás, szállítás és további üzleti folyamatok során.
Fontos különbséget tenni a társadalmi felelősségvállalás, a vállalati elszámoltathatóság és a compliance menedzsment fogalmai között. A társadalmi felelósségvállalás (corporate social responsibility, CSR) egy üzleti fogalom, amely szerint a vállalatok önszabályozási folyamatokon keresztül figyelembe veszik a társadalom érdekeit, mégpedig azáltal, hogy tevékenységükben tekintettel vannak üzletfeleikre, beszállítóikra, alkalmazottjaikra, tulajdonosaikra és a környezetre. A társadalmi felelôsségvállalás túlmutat a jogszabályok szavainak és szellemének betartásán, a társadalom bizonyos csoportjait támogató vállalati adományok tipikus példái a társadalmi felelősségvállalásnak.

Az átláthatóság és az elszámoltathatóság szorosan kapcsolódó fogalmak, a jó vállalatirányítási gyakorlat fontos elemei. Az átláthatóság felöleli a hosszú távú gondolkodást, a fenntartható múködést, az elszámoltathatóság érinti a beszámolási kötelezettséget (pénzügyi és nem pénzügyi jelentések), a szervezeti felépítést, a stratégiát, az eljárásokat és a tevékenységeket.

A gazdálkodó szervezetek mindennap jogi és etikai kockázatoknak vannak kitéve. A jelenlegi nagyon gyorsan változó gazdasági, szabályozási és társadalmi környezetben a hagyományos kockázatkezelés kiegészül egy újabb szempontú törekvéssel. A compliance menedzsment célja a szabálytalan múködésból eredő 
1. ábra nyomon követő kiegyensúlyozott mutatószámrendszer,

A compliance menedzsmentre ható menedzsmentmegközelítések

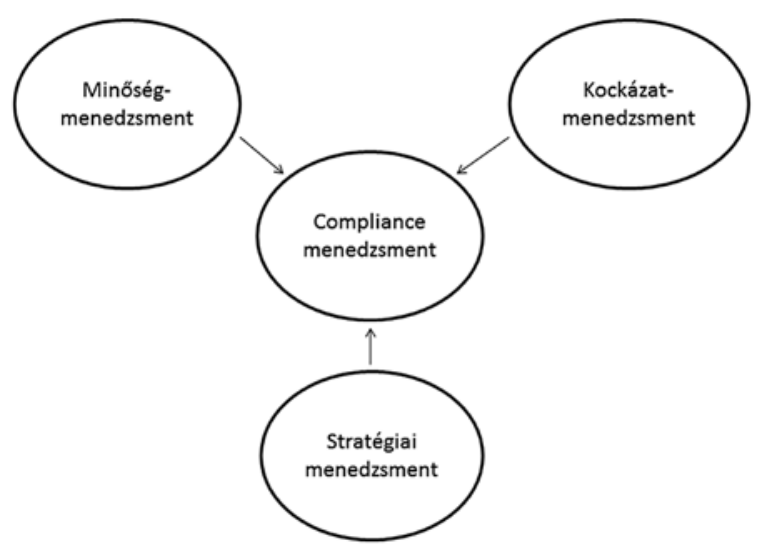

kockázatok csökkentése. Felvetődik a kérdés, hogy vajon a vállalati compliance, az elvekben, tervekben, eljárásokban, törvényekben, szabályozásokban, szerződésekben és más követelményekben megfogalmazottak betartása, röviden a szabályszerú múködés, a megfelelés fejlesztése hogyan járul hozzá a vállalatok gazdasági hatékonyságához, ki és hogyan értékelheti a vállalati compliance tevékenységeket, hogyan mérhető a compliance menedzsment teljesítménye. A vállalati szintú compliance értékelés célja e tevékenység által támogatni a szervezetet stratégiája, céljai elérésében.

Jelen cikk a compliance menedzsmentjének szervezeten belüli értékelését tárgyalja. Az elsố részben a compliance menedzsment definícióját, értelmezését tárgyaljuk. Ezt követốn a vállalati önszabályozás három szakasza kerül bemutatásra. A harmadik résztől kezdve - a vállalati compliance menedzsment érettségétől függóen - három lehetséges értékelési szempontot mutatunk be, az egyes részeket mintakérdésekkel zárva. A cikk következtetésekkel és megjegyzésekkel zárul.

\section{A compliance menedzsment fogalmáról}

A compliance menedzsment azon folyamatok összessége, amelyek célja, hogy biztosítékot nyújtson a szabályszerú, eredményes és hatékony múködés, valamint a megbízható beszámoló elérésére. Ezt a célt a szervezet a szabályszerútól eltéró tevékenység vagy eredmény megelőzése, feltárása, korrekciója révén próbálja elérni. A compliance menedzsment minden szinten és értelemben a gondos munkavégzést támogatja, a belsố folyamatok kialakításától elkezdve, a minőségellenőrzésen keresztuil a szervezeti kultúráig.

A compliance menedzsment három fó terület egyidejú múködését feltételezi. Ezek a stratégiai menedzsment (pl. a stratégiai célok megvalósulását elôsegítő és a Balanced Scorecard alkalmazásával), a múködés és szabályszerúség irányításában alkalmazott minőségmenedzsment (pl. Total Quality Management, TQM), és a beszámoló megbízhatóságát és a pénzügyi megfelelőséget garantáló kockázatmenedzsment (1. ábra).

Röviden, a compliance menedzsment adott vállalat hatékony irányításához nyújt segítséget változó gazdasági környezetben, a belsố múködés szabályosságát, megfelelőségét és a stratégiával való összhangját tartva szem előtt. A compliance értékelés a vezetốk számára naprakész és releváns információkat szolgáltat a compliance kockázatok kezeléséhez. Többek között visszajelzést ad a compliance tervektól való eltérésról, a változásokról, az erơforrások felhasználásáról, továbbá támpontot nyújt fejlesztési javaslatok kidolgozásához.

A governance, risk and compliance (GRC), magyarul irányítás, kockázat- és compliance menedzsment egy átfogó megközelítés a fejlett gazdasági szervezeteknél, mely rámutat, hogy a felelős vállalatirányítás, a belsố ellenôrzési mechanizmusok, a kockázat- és a compliance menedzsment területei szorosan összefüggnek. E területeknek az átfedések és a hiányosságok elkerülése érdekében összehangoltan célszerú múködniük.

A compliance értékelésnek szintén célja a hiányosságok azonosítása, értékelése. Fontos kérdés, hogy a compliance szervezet betölti-e célját, hozzáadott értéket képvisel-e a szervezet számára, azaz annak megítélése, hogy a compliance szempontjából bekövetkezett javulás mennyiben és hogyan járul hozzá a vállalat sikeréhez. Egy szervezet compliance tevékenységének eredményességét ugyanúgy lehet mérni és értékelni, mint bármely más termelô vagy szolgáltató tevékenységét. A tervek és a tényadatokat összevetése, rendszerezése, elemzése értékes információkat szolgáltat a döntéshozók számára. Az értékelés egyben tanácsadói feladat is, mely adott esetben a felmerülő problémákra kínál megoldási alternatívákat.

\section{A vállalati önszabályozás három szakasza}

A compliance menedzsment három fejlődési szakasza különböztethető meg Parker (Parker, 2002) szerint, ahogy az a 2. ábrán is látható. Az elsó szakaszban felmerül az igény a vállalati önszabályozás fejlesztésére, jellemzően valamilyen jogi vagy üzleti értelemben vett új helyzet hatására. Elkezdődik egy rendszerezett tevékenység, általában a kockázatkezelés vagy a jogi tevékenység részeként, valamint annak eróforrásait használva, melynek célja a compliance menedzsment határainak kijelölése, feladatainak áttekintése, a 
tevékenység megtervezése és a kontrollok kialakítása. Ebben a szakaszban elótérbe kerül a legjobb iparági gyakorlat feltérképezése és az üzletágak múködésének mérése, összehasonlítása.

A compliance múködési területe (scope) szervezetenként változó, az adott szervezetnél felmerülő problémákkal, kockázati területekkel összhangban kerül meghatározásra. Ebben a kérdésben a tevékenységi kör, a vállalat mérete és az iparág mind jelentős tényezók. Általában a kockázatok köréból a következốkkel foglalkozik a compliance menedzsment (Lipton et al., 2008):

- vállalati csalás,

- korrupció, megvesztegetés,

- termékbiztonság,

- környezetvédelmi compliance,

- IT-kockázatok,

- szellemi tulajdon,

- antitröszt compliance,

- szociális felelôsségvállalás,

- reputációs kockázat,

- emberi jogok.

A compliance területének, határainak kijelölése kritikus fontosságú, hiszen a túl tágan értelmezett feladatkör esetén nem várható minden egyes területen értékelhetô eredmény. is értesülnek az esetekrôl. Vétségek esetén a vállalat kidolgozott folyamatok alapján szankcionál, kezeli a fellépó üzleti kockázatot. Az önszabályozás kapcsán a szervezet együttmúködik különféle szakmai csoportokkal, jogalkotókkal és egyéb jogi szervezetekkel vagy hálózatokkal. A vállalat munkatársai compliance képzéseken vesznek részt, megkezdődik a compliance megközelítés integrációja a mindennapi üzleti folyamatokba.

Egy bejáratott rendszer esetében a compliance értékelés a megtervezett és írásban rögzített compliance folyamatok és a valós alkalmazás összhangját vizsgálja. Az eseti vagy rendszeres kockázatfelmérés, az éves felülvizsgálat lehetővé teszi új kockázatok azonosítását, a compliance folyamatok és kontrollok fejlesztését.

A harmadik szakaszba akkor lép egy vállalat, amikor a compliance folyamatos visszacsatolási és fejlesztési tevékenysége sikerrel jár, az önszabályozás folyamatai biztosítják a belsố és külsô megfelelés célként rögzített szintjét. Fontos megemlíteni, hogy a compliance megközelítés elméletileg megengedi a tudatosan szabálytalan múködést, amennyiben a megfelelés költségeit a szabálytalan múködés költségeivel - beleértve a leleplezés esetén kiszabott büntetést, szankciókat, a reputáció romlását, a szerződésszegés következményeit - összevetve a szervezet így dönt (a költség-haszon elv alkalmazása

2. ábra alapján). Ilyen esetekben a vállalat folytatja a jogszerútlen gyakorlatot, azonban az ehhez kapcsolódó compliance kockázatot számszerúsíti és felszámolását jövôbeli, tervezett feladatai között tartja számon. Tehát ebben a szakaszban a compliance a szervezeti kultúra részévé válik, és a mindennapi üzleti folyamatokban integráltan jelenik meg.
3. szakasz

\begin{tabular}{|l|l|}
$\begin{array}{l}\text { Compliance munkacsoport } \\
\text { és tevékenységek } \\
\text { kialakítása, } \\
\text { kockázatkezelés, } \\
\text { kommunikáció, jelentések }\end{array}$ & $\begin{array}{l}\text { Én, visszacsatolás, } \\
\text { tanulás, folyamatos } \\
\text { fejlesztés }\end{array}$ \\
\hline
\end{tabular}

2. szakasz

Az érettséget lépésról lépésre, sorozatos visszacsatolások által, fokozatosan éri el egy szervezet, és ebben fontos szerepe van a vállalati önértékelésnek, teljesítménymérésnek. Fokozatosan nố a compliance belsố folyamat tanácsadói és döntéstámogató szerepe.

Célszerú figyelembe venni, hogy egy adott szervezet compliance tevékenysége az érettség milyen szintjét érte el, mivel az egyes fejlódési szakaszokban különböző értékelési technikákat eltérő hatékonysággal lehet használni (Parker, 2002). Egyes iparágakban a felügyeleti hatóságok már eleve meghatároznak egy bizonyos fokú érettséget (pl. pénzügyi szolgáltatások). A következő három fejezetben az értékelésról lesz szó részletesebben. Azonban azt is szem elôtt kell tartani, hogy az értékelések mintegy egymásra épülnek, azaz a tervezés értékelése nemcsak a kezdeteknél, hanem egy 
évek óta múködő rendszernél is lényeges. Kialakult, stabil compliance menedzsment esetén pedig továbbra is érdekes a compliance tervek és a tények összevetése a stratégiai hatások, megtérülések vizsgálata mellett.

\section{A compliance rendszer értékelése}

\section{Tervezés, kialakitás}

A compliance tevékenység létrehozása egyfajta kihívás, egy lehetôség a kiváló üzleti teljesítmény támogatására. A compliance szervezet a vállalat üzleti céljait, a hatékony vállalatirányítást igyekszik támogatni azzal, hogy meghatározza a jogszerú és etikus magatartás határait, a hatósági követelmények és a szervezet saját belsố szabályozásának ismeretében.

Már a tervezés során elengedhetetlenül fontos a felső vezetôk elkötelezettsége, nemcsak a szavak, hanem a tettek szintjén is. A szabályszerú magatartás elsôsorban a legmagasabb döntéshozó szint (közgyúlés, igazgatóság, felügyelóbizottság) által meghatározott. A törvénytisztelő, szabálykövető, felelősségteljes vállalati magatartás a stratégia része, egy vállalati érték, a szervezeti kultúra eleme. A compliance tevékenység megszervezésére felsővezetői döntés alapján alakítható ki külön szervezet, itt jelölik ki a felelős személyeket és a pénzügyi kereteket. Gondos, példamutató vezetés nélkül lehetetlen látványos és tartós compliance eredményeket elérni. Vajon mit tehet a vezetés azért, hogy a szervezet szabályszerúen, megbízhatóan és felelős módon múködjön?

A vállalati compliance rendszerekkel szemben támasztott elvárások területén az USA szolgál a leginkább kidolgozott mintákkal. Az egyedi önszabályozás esetében egyértelmú az 1991-ben kiadott Szövetségi Mértékadó Útmutató Szervezeteknek (Federal Sentencing Guidelines for Organizations, FSGO), mely útmutató olyan követelményeket állít, amelyekhez egy compliance és etikai programnak meg kell felelnie ahhoz, hogy „hatékony” legyen. Az eredeti, leginkább közszolgálatokban alkalmazott FSGO felülvizsgálatra került 2004-ben. A módosítások elsôsorban a vezetés kezdeményező szerepére vonatkoznak, valamint beemelték a vállalati etikát a szabványba. Silverman alapján a fő́bb útmutatások a következók:

- compliance szabványok és eljárások kialakítása, melyek leírják, hogy a vállalat milyen magatartást vár el munkavállalóitól és üzleti partnereitôl,

- felső vezetôk megbízása a compliance tevékenységek adminisztrációjával és felügyeletével,

- korábban illegális tevékenységben résztvevő vagy arra hajlamos személyek önálló hatáskörrel való felruházásának megelôzése,

- a szabványok és eljárások hatékony kommuniká- ciója az összes alkalmazott felé, például képzési programok és kiadványok formájában,

- nyomon követés és jelentési rendszerek kialakítása (pl. vészjelzó programok),

- a helyes magatartás következetes kikényszerítése fegyelmi mechanizmusok által,

- szabálytalanság, búncselekmény észlelése esetén a szervezet minden ésszerú lépést megtesz, hogy megelőzze a jövốbeli hasonló eseményeket (ideértve a compliance tervek módosítását is).

2002-ben az Egyesült Államokban elfogadták a Sarbanes-Oxley törvényt (SOX). Ez a törvény újdonságokat hozott a pénzügyi beszámolás, a könyvvizsgálat és a belsố irányítás területein a nyilvánosan múködő társaságokra vonatkozóan. Egy szervezet vezérigazgatója (CEO) és pénzügyi igazgatója (CFO) személyesen is felelős a negyedéves és éves pénzügyi jelentések teljességéért és pontosságáért, továbbá az alapul szolgáló információkra vonatkozó belsố kontrollok hatékonyságáért. A legnagyobb jelentôséggel a 404-es szakasz bír, amely megköveteli a pénzügyi jelentéseket alátámasztó belső kontrollok éves értékelésének közzétételét az éves pénzügyi beszámolók részeként. A SOX a vállalati magatartásban a vezérigazgatót és a gazdasági vezérigazgató-helyettest fokozott felelősséggel ruházza fel. A törvény alapja az az elgondolás, hogy a vállalati szektorban nemcsak az üzleti eredmények, de a vétségek, kudarcok nyilvánosságra hozatala is erősíti az általános üzleti bizalmat.

A Treadway Bizottságot támogató szervezetek bizottsága (The Committee of Sponsoring Organizations of the Treadway Commission, röviden COSO) egy önkéntes szervezet, melyet több szakmai csoport alkot. Több mint húsz évvel az eredeti verzió után, a 2013. május 14-én közzétett, frissített COSO Vállalkozások kockázatkezelése - integrált keretek (COSO Internal Control - Integrated Framework) keretrendszer, és az ahhoz kapcsolódó szemléltető dokumentumok, együtt egy széles körben használt, a SOX-nak megfelelő értékelési keretrendszert alkotnak. Ez az amerikai keretrendszer a belsố kontrollrendszer fogalmát így határozza meg: „a belsố kontroll egy folyamat, amelyet a társaság igazgatósága, a menedzsment és az alkalmazottjai valósítanak meg, és amelyet azért hoznak létre, hogy a múködési, jelentéstételi és compliance célok elérését illetôen ésszerú bizonyosságot nyújtsanak" (COSO, 2013: p. 3.).

A COSO-keretrendszer megfelel az amerikai Értékpapír és Tőzsdefelügyelet (U. S. Securities and Exchange Commission, röviden SEC) négy kritériumának (Tarantino, 2008: p. 72.): 
1. elő́télet-mentesség,

2. lehetővé tesz ésszerúen konzisztens minőségi és mennyiségi méréseket a cég belsô ellenôrzésére vonatkozóan,

3. kellően teljes, azaz a vállalat belsố ellenốrzési rendszerének hatékonyságát vizsgáló mérésekból nem hagy ki releváns tényezôt, amely megváltoztatná a végsố következtetést,

4. releváns a belsố ellenőrzés és a pénzügyi jelentések összevetésében.
A COSO-keretrendszer alapján elmondható, hogy a hatékony, ésszerú compliance menedzsmenttel rendelkezô szervezet (COSO, 2013: p. 8.):

- megvalósítja a hatékony és eredményes múködését (vagy a negatív külső események hatását elfogadható szinten képes tartani, hiszen előre számolt az eseményekkel),

- megérti, hogy milyen mértékben képes hatékonyan reagálni az üzleti célokra jelentôs hatással bíró eseményekre,

3. ábra • az alkalmazandó szabályok, szabványok vagy a szervezet meghatározott jelentéstételi célkitúzései szerint készíti beszámolóit, jelentéseit,

- múködése megfelel a hatályos törvényeknek, jogszabályoknak, rendeleteknek és külsố szabványoknak.

A COSO-keretrendszer és az FSGO-útmutatások jelentôs hatást gyakoroltak annak megítélésére, hogy

Forrás: Rendszer-ellenőrzési módszertan, 4. o.

A COSO-modell a belsố kontroll öt komponensét különíti el, mindegyik kontrollkomponens a szervezeti célok (múködési, pénzügyi jelentéstételi, törvényi megfelelés) és a szervezeti egységek szerint más tartalommal bír, ezt ábrázolja a 3. ábra.

A COSO-keretrendszer célja olyan normák felállítása, amelyekhez képest az üzleti vezetôk értékelni tudják a belsố ellenôrzési rendszereket. Az eredeti COSOkeretrendszer létrejötte óta a világban ugrásszerúen megnőtt az érdeklódés nem pénzügyi jelentések iránt, ilyen például a SOX 404-es szakasza szerinti belsố ellenôrzési jelentés. Számos kritika érte a keretrendszert, melyet 2013-ban a következő célok figyelembevételével újítottak fel:

- a hatékony belső ellenôrzés követelményeinek tisztázása,

- az üzleti és múködési környezetben bekövetkezó változások esetén a belső ellenôrzés hatókörének frissítése,

- az alkalmazás körének bóvítése a múködési és jelentéstételi célokban, a szemléltetô eszközök biztosítása a belső ellenôrzést bevezető vagy értékelố vállalatok számára,

- speciális módszerek és példák bemutatása a külsố pénzügyi beszámolókra vonatkozó valós vállalati tapasztalatokról. mi az üzleti életben elfogadható gyakorlat, milyen belsố kontrollok szükségesek. Egy compliance rendszer tervezését aszerint is lehet értékelni, hogy mennyiben felel meg az FSGO vagy egyéb, az önszabályozás keretein belül választott előírásoknak (pl. ISO 26000, ISO 14000).

Globális szintre lépve elmondható, hogy az elmúlt másfél évtizedben a legnagyobb nemzetközi szervezetek (pl. ENSZ, Világbank), továbbá a nemzeti kormányok szintén kialakítottak és kiadtak számos általános és tematikus irányelvet, a legjobb üzleti gyakorlatra vonatkozó ajánlást, mint például az OECD elvei a vállalati kormányzásról (2004), Nemzetközi vállalkozások és egyéb üzleti szervezetek felelősségi normái az emberi jogokra való tekintettel (2003), ENSZ Globális Megállapodása (2000), ENSZ Felelôs Befektetések Elvei (2006). Mind az OECD elvei, mind a SOX nagy hatást gyakoroltak a magyarországi gazdasági társaságok gyakorlatára.

Mivel minden szervezet különböző, ezért minden compliance terv egyedi. Mindazonáltal van néhány általános elem, amit egy ilyen tervnek tartalmaznia kellene:

- a belsố fegyelmi rendszerhez való kapcsolódás,

- a jogsértő események, panaszok megelőzése, felderítése, felkészülés ezen esetek kezelésére és a negatív következményekkel szembeni védelem, 
- a felsố vezetés, a compliance szervezet és a munkavállalók szintjén meghatározott felelősség azonosítása és szétválasztása,

- a folyamatok és a teljesítmény rendszeres mérése és folyamatos fejlesztése.

\section{A compliance funkció kialakítását értékelö mintakérdések:}

- Milyen törvényeknek, jogszabályoknak kell megfelelnie az adott szervezetnek? A vállalat megfelel a fentieknek?

- Milyen felelőssége, kötelezettségei vannak az igazgatóságnak és milyen kötelezettségei vannak a menedzsmentnek? Mi biztosítja a funkciók függetlenségét?

- Milyen etikai elveket képvisel és alkalmaz a vezetés a szabályszerú múködésben?

- Milyen határai, korlátai vannak a compliance tevékenységeknek, a compliance szervezetnek? Milyen kapcsolatban áll a könyvvizsgálattal, a belsố ellenốrzéssel, a jogi részleggel és a kockázatkezeléssel?

- Milyen ajánlások, standardok szerint valósul meg a compliance eredményességének éves felülvizsgálata?

- Milyen partnerekkel, szabályozó hatóságokkal, szakmai csoportokkal áll kapcsolatban a szervezet?

- Milyen üzletági legjobb gyakorlatok hasznosak az értékelésben?

- Milyen stratégiai és múködési célokból indul ki a kockázatértékelés? Milyen folyamat szerint, milyen rendszerességgel vizsgálják felül a kockázatokat?

- Milyen kockázatok körére terjed ki a compliance menedzsment?

- Milyen üzleti változások jelentenek kihívást a compliance tevékenységekben?

- A compliance tervek minden szükséges elemet tartalmaznak?

\section{Tevékenységek, múködés}

A compliance tervek végrehajtása számtalan nehézséget okozhat, ellenben óriási lehetőségeket rejt az üzleti kiválóság fokozására. A compliance szervezet egyik fő feladata a kockázatokból kiindulva az elvárások meghatározása (pl. útmutatók, irányelvek, folya- matok szintjén), a nem megfelelőség potenciális költségeinek becslése a megfelelés költségeivel szemben, prioritások meghatározása, a kockázatok rangsorolása, a szükséges korrekciós tevékenységek kezdeményezése. Mivel a kockázatok szüntelenül változnak, ezért a kezelésükre hivatott kontrollrendszernek is folyamatosan változnia kell.

A compliance menedzsment számos tevékenységet foglal magába, például:

- a külső és belsố szabályzatok figyelése, frissítése, betartatása,

- kockázatértékelés, kontrollok kiépítése,

- szabálytalan vagy jogsértő esetek felderítése, kezelése, korrekciója,

- munkavállalók, partnerek és szervezeti csoportok (pl. igazgatóság) compliance specifikus oktatása,

- kommunikáció külső és belső csoportokkal, névtelenséget lehetővé tevő́ bejelentôvonalak (riasztási rendszer) létrehozása, múködtetése,

- a fentiek dokumentációja, mérése, értékelése (pl. audit).

A compliance munkatársak szisztematikusan átvizsgálják az üzleti folyamatokat és ellenôrzik a szabályozásnak való megfelelést. Az írott előírásokon túl a szabályozás szellemiségét, a szabályozási célokat is szem elốtt kell tartani. Nagy komplexitású feladatokat is kezelni kell, például akár csak egy termékhez kapcsolódóan is compliance kérdések merülhetnek fel a beszerzés, a gyártás, a minőség-ellenôrzés és az értékesítés folyamatában. Hogy a termék minden szempontból megfelelô legyen, a szervezetnek szüksége van egy bizonyos szintú ellenőrzésre az ellátási lánc minden pontján.

Alapvető tevékenység a kommunikáció: az üzleti egységek felé, hatóságok, külső partnerek felé, igazgatóság felé (beszámolók), munkavállalók felé (célok, tervek, etikai kódex) és csatornák biztosítása a munkavállalóktól a compliance csoport vagy vezetố felé.

A compliance csoport sajátos feladata a nem megfelelôségi ügyek felkutatása, kezelése. Az etikátlan vagy törvénytelen magatartással a felderítéstól, vagy az alkalmazottaktól érkezô jelzéstốl kezdve rövid idő́n belül foglalkozni kell. A korrekciós és a megelôző intézkedések szorosan kapcsolódnak egymáshoz.

Példa egy adott compliance ügy kezelésére: egy Global 100-as cégnél - a világ száz leginkább fenntartható nagyvállalatának egyikénél - a belsố ellenórzés felfedte, hogy a szerzódések be nem tartása a belsố szabályok betartásának és a doku- 
mentumok rögzitésének hiányából fakad. Elóször a probléma pontosítása, a helyzet feltárása történt meg. A szerzódéskötési folyamatban nem volt megfeleló a belsó kontrollok kiépítése, valamint számos megállapodás az elfogadott szabványokon kívïl készült. A szabályszerü múködés felé az elsó lépés a szerzôdés-adatbázis átépítése volt. Ez már illeszkedett a vállalat fö adatbázisrendszeréhez, majd új ellenórzési pontokat építettek a szerzódések adminisztrációjába.

A nyitott szervezeti kultúra támogatja a munkáltatókat a bejelentésekben, előtérbe helyezi az egyes ember felelősségét. Ideális esetben a szervezetben nem jellemző a következményektől, a lehetséges megtorlástól való félelem. E folyamatban a munkavállalók megfelelő képzése és tájékoztatása, valamint a névtelenséget lehetôvé tévő kommunikációs csatornák biztosítása a felsô vezetés és a compliance szervezet közös feladata.

Az oktatás egyik részfeladata a minden munkavállalóra kiterjedő kötelezô compliance képzések létrehozása, lefolytatása, adminisztrációja és értékelése, továbbá folyamatos frissítése, fejlesztése. Ezen túlmenóen speciális munkaköri képzésekre is szükség lehet. Általános elem az új munkavállalók induló tréningje.

És végül, a compliance szervezet feladata a rendszeres ellenőrzés, audit. Egy jól felépített és teljességében múködő compliance szervezet rengeteg konkrét változást hoz az adott szervezeti és üzleti folyamatokba. Az élenjáró vállalatok számos folyamatértékelést fejlesztettek ki, például (Parker, 2002):

- munkavállalói képzési részvétel nyilvántartása, külön képzési kérelmek, a forródrót-szolgáltatás használata, a jogsegély-útmutatók használata,

- az alkalmazottak compliance tudását/tudatosságát mérő tesztek, IT-alapú képzés,
- az elkerült potenciális költségek nyomon követése, vagy a hatékonyságnövelés hozzáadott értéke,

- a compliance beépítése a munkaköri leírásokba és az egyének teljesítményértékelésébe.

A compliance program megvalósításának értékelésére hasznos eszköz a minôségbiztosítási vagy a belsô ellenórzési szabványokhoz hasonló belsô audit. Itt felmerül a kérdés, hogy kijelölhető-e független belsô auditor (pl. másik részleg, belső ellenőrzés). A külső audit előnye a függetlensége, hátránya a nagyobb költség lehet. Vegyes megoldás, ha egy független auditor ellenőrzi az önvizsgálatot.

Az audit tartalma vállalatonként mást takar, hiszen a stratégiai célokból meghatározott kockázatok szerint minden szervezetnél más és más területekre terjed ki a compliance menedzsment. Az auditorok feladata egy saját üzleti kockázatértékelés elvégzése, számba véve, mi minden veszélyezteti az üzleti célok elérését. Az audit feltárhat olyan kockázatokat, amelyekról addig a szervezetnek tudomása sem volt.

Az alkalmazott módszerek a dokumentációk, formai elemek ellenôrzésétől, az interjúkon és kérdőíveken keresztül, a kreatív értékelő terepmunkáig (pl. álbejelentések, titkos vásárlás, biztonsági riasztás, fókuszcsoportok) terjedhetnek. Többek között nemzetközi könyvvizsgálati, minôségbiztosítási, belsô ellenôrzési szabványok lehetnek az auditor segítségére (pl. IAS 240 és SAS 99 a csalás ellenôrzésére vonatkozóan). Gyakori probléma, hogy a meglévő számviteli és adminisztrációs rendszerek nem adnak elegendő és megbízható minôségú információt a compliance menedzsment értékeléséhez.

A változó körülmények miatt minden értékelés feltár problémákat és olyan dolgokat, amelyeken változtatni lehet vagy szükséges. Az értékelés bizonyos tekintetben vitatémákat vet fel és a compliance rendszer változását ösztönzi. Az audit a compliance rendszer teljesítményét ösztönzi, amennyiben képes párbeszédet kezdeményezni és rámutatni tervezési és végrehajtási hibákra.

\section{Példák a compliance tevékenységek értékelését célzó kérdésekre:}

\section{- Eróforrások:}

o Rendelkezésre állnak az informatikai rendszerek, emberi, pénzügyi és egyéb eróforrások a tervek kivitelezéséhez? Ha nem, mely területeken vannak hiányosságok? A részmunkaidóben compliance feladatokat végző munkatársak feladata, felelőssége arányban áll az allokált idôvel? Milyen érdekkonfliktusok jelentkeznek náluk? o Hogyan biztosítja a szervezet a jó minóségú, naprakész információkat a compliance szervezet számára? Milyen akadályozó tényezók, korlátok léteznek?

\section{- Szabályozás, eljárások:}

o Milyen elvárt compliance tevékenységeket rögzítenek a múködési politikák, belsô szabályzatok, és milyen eljárások kapcsolódnak ezekhez? 
o Létezik írott etikai kódex? Milyen széles körben ismert a tartalma? A szervezetben használt minden nyelven elérhetó?

o Milyen vétójogokkal rendelkezik a compliance szervezet (pl. termékvisszahívás, új termék bevezetése vagy szervezeti változás késleltetése, megakadályozása)?

o A munkaszerződések tartalmazzák az egyéni felelősség és a törvénysértô esetek bejelentési kötelességének leírását?

- Ügykezelés, felderítés, megelózés, korrekciók, fegyelmi rendszer:

o A compliance szervezet kezelte az elmúlt időszakban felmerült jogsértő, szabályellenes eseteket? Ha nem, miért nem, és milyen korrekciók történtek?

o Mennyire fejlett és hatékony a visszaélések felderítése? Hogyan javítható?

- Oktatás:

o Az alkalmazottak kaptak képzést, tájékoztatást a munkájukra vonatkozó szabályokról, azok alkalmazásáról? Milyen tendenciát mutat a képzéseken való részvétel? Milyen nehézségek merültek fel (pl. időbeosztás, módszertan stb.)?

o Az oktatók kellóképpen tapasztaltak, képzettek a compliance témakörében?

o Milyen vissszajelzések érkeztek a compliance tréningekról?

o Tudja minden munkavállaló, hogy ki a compliance vezetô, és hogy mivel foglalkozik? Mennyire egyértelmú az ő szerepe a szervezeten belül?

o A compliance által számításba vett kockázatokhoz kapcsolódó külső partnerek milyen képzésben részesültek?

o A compliance szervezetet felügyelő igazgatósági tagok milyen képzésben részesültek?

o Milyen következményekkel jár a kötelező compliance tréningekból való kimaradás?

- Kommunikáció, riporting, felelósségi körök, egyéni felelōsség, elszámoltathatóság:

o Milyen problémák jelentkeztek a könyvvizsgálattal, a belső ellenőrzéssel, a jogi részleggel és a kockázatkezeléssel való együttmúködésben? o Milyen problémák jelentkeztek a szabályozó hatóságokkal való kapcsolattartásban?

o A szabályozási változásokról, eljárások frissítésérôl, korrekciós tevékenységekről időben és pontosan tájékoztatást kapnak az érintett szervezeti egységek?

o Az új termékek, szolgáltatások, szervezeti változások és egyéb compliance szervezetet is érintố kérdésekrôl valós, rendszeres kommunikáció és együttmúködés van a compliance szervezet és az üzleti egységek között?

o Milyen kommunikációs csatornák állnak rendelkezésre a compliance problémák bejelentésére? Vannak anonim csatornák? A csatornák közül melyeket nem használják a munkatársak? Mi az oka ennek, szükséges-e fenntartani ezeket? Arányban vannak-e a bejelentési lehetőségek a szervezet méretével, struktúrájával? Milyen trendek, minták észlelhetók?

o Milyen szankciókat von maga után a törvénysértố események elhallgatása? Milyen okai vannak (pl. gondatlanság, tudatlanság, cinkosság stb.)?

o A bejelentők hogyan kapnak visszajelzést?

o Előfordul a bejelentések megtorlása? Milyen folyamatok vezetnek ehhez? Eltúri vagy támogatja a szervezeti kultúra a megtorlást? Félnek a munkavállalók a bejelentő vonalak használatától?

o A compliance hiányosságokat a vezetô időben és a megfelelő csatornákon keresztül továbbítja az igazgatóság felé?

\section{- Ellenôrrzés, monitoring, audit:}

o A méretnek és a múködésnek megfeleló rendszerességú auditot folytat a szervezet? Létezik írott compliance audit terv? Milyen témaköröket foglal magába? Milyen módszereket, rendszerességet ír elő?

o A korábbi auditok által feltárt problémákat nyomon követik valamilyen formában? Korábbi panaszok, ügyek által érintett területekre kitér a következó audit?

o Milyen szervezeti szint számolhatja el az audit költségeit?

o Mi biztosítja az auditorok objektivitását, hogyan valósul meg az auditorok függetlensége? 


\section{Teljesítmény, eredmények}

$\mathrm{Az}$ aktuális mindennapi és a stratégiai kihívásokra reagálva a szisztematikus compliance tevékenységek kézzelfogható előnyöket és eredményeket céloznak meg. A compliance menedzsment érettségének előrehaladtával, az értékelés eltolódik az erófeszítésektôl a teljesítmények, hatások irányába (HCCA, 2003: p. 7.). Például a compliance kiteljesedésével arányosan csökkennie kell a kötelezố compliance témájú képzésekból kimaradó alkalmazottak számának. Tehát ezek a mutatók már kevésbé hasznosak az értékelésben.

Egy adott szervezetnél a compliance menedzsment fejlődése néha kacskaringós utat jár be. Új termékek vagy szolgáltatások bevezetése, új piacok integrációja, változó szabályozási környezet, vállalatfelvásárlás, csốd vagy egyéb lényeges változások mind kihívást jelentenek a compliance szervezet számára. Minden ilyen esemény időszakosan ronthatja a belső kontroll érzékelt szintjét. Lehetséges, hogy nehéz összehasonlítani egymást követô időszakokat, hiszen egyszerre több lényeges tényező is megváltozik. Mégis, a compliance költségeknek és a hasznoknak valamiféle pozitív korrelációja a cél. A vállalat által befektetett emberi, anyagi ráfordításoktól elvárt eredmény a valós, releváns kockázatok csökkentése, ésszerú költségszint mellett.

Vajon hogyan biztosítja a szervezet, hogy a múködés valóban a jogi és társadalmi követelményeknek megfelelóen történjen (pl. termékbiztonság)? Pontosan erre kíváncsiak leginkább az érintettek (szabályzó testületek, részvényesek stb.). A felsố vezetés számára a kérdés, hogy a compliance szervezet betölti-e célját, hozzáadott értéket képvisel-e, a compliance szempontjából bekövetkezett javulás mennyiben járul hozzá a vállalat sikeréhez. A vállalati önszabályozás harmadik szakaszában az eredményeket a cég teljes compliance rendszerének szemszögéból kell elemezni.

Vajon hogyan használhatja fel a vállalat a saját megfigyeléseinek (önértékelésének) eredményeit a compliance rendszer fejlesztéséhez? Egyfelól, az önértékelés számos tervezési és végrehajtási problémát feltár, melyeket önállóan orvosolni kell (ideértve a szabályozó hatóságok felé benyújtott jelentéseket is).

Másfelól, a compliance önértékelés a döntéshozatalt javíthatja, mivel az értékeléshez egy bizonyos szintú vállalati önismeret elengedhetetlen, és a nagyobb vállalati önismeret versenyelónyre váltható át. Az eredmények közzététele elősegíti a belső párbeszédet a vállalati compliance gyakorlatról, így segíti a szervezeti kultúra megújulását is. A pozitív eredményeket szélesebb körben nyilvánosságra lehet hozni, hiszen ezek a vállalat iránti általános bizalmat építik.
Az önértékelésben segítség lehet egy compliance teljesítménymérés és jelentés támogatására kidolgozott keretrendszer és útmutató, melyet az Open Compliance and Ethics Group, egy nonprofit szervezet fejlesztett ki. Az OCEG mérési platform középpontjában az üzleti célok állnak. Annak érdekében, hogy a compliance program a kívánt eredményeket hozza, a következó három jellemzôt érdemes vizsgálni: hatékonyság, eredményesség és válaszkészség. Mivel jelen cikkben a három szakaszra bontott értékelés részletesen tárgyalja a hatékonyságot (a tervezés és a múködés hatékonysága) és az eredményességet, ezért itt csak az utolsó jellemzốre térünk ki.

A szervezet válaszkészségét két dimenzióban érdemes vizsgálni: ciklusidő és rugalmasság. A ciklusidő egy folyamat végrehajtásának teljes idôtartamát jelenti. A rugalmasság megmutatja, hogy milyen mértékben képes a rendszer integrálni az új üzleti egységeket (egyesülés, felvásárlás során) vagy az új követelményeket (pl. új törvények, piaci feltételek változása, kiigazítás korábbi compliance értékelés nyomán, új partnerek, új technológiák, új médiafelületek, mint Facebook stb.). Egy érzékeny, válaszkész compliance munkacsoport gyorsan alkalmazkodik a környezeti változásokhoz, valamint képes felkészülni az elôrevetített jövőbeli változásokra.

\section{A compliance rendszer}

teljesítményének értékelése többek között a következó kérdésekkel foglalkozik:

- Milyen bizonyítékok vannak arra, hogy a compliance rendszer kialakítása megfelel a választott szabványoknak, és a szervezet számára releváns kockázatokat veszi figyelembe?

- Milyen bizonyítékok vannak arra, hogy a compliance megvalósítása az egész szervezetet lefedi?

- Hogyan mutatható be a tényleges változás az emberek tudásában, viselkedésében, hozzáállásában, a szabálysértések számában stb.? Hogyan alakult a forródrót és egyéb bejelentô csatornák használata az elmúlt időszakokban? Milyen hatékonysággal múködik a panaszkezelés? Az audit kevesebb hibát talál a compliance által frissített eljárások alkalmazásában?

- Milyen hatással vannak a compliance tevékenységek a szervezeti kultúrára?

- Hogyan mutatható be, hogy a vállalat compliance programja valóban hozzájárul a társadalmi 
értékekhez, pl. környezeti állapot megốrzése a környéken, fogyasztói tájékoztatás, biztonságos munkahely, a hátrányos megkülönböztetés és zaklatás hiánya stb.?

- Milyen súlyú játékos a compliance szervezet a döntéshozatalban, a hatalmi struktúrában? Milyen szerepe van a compliance értékelésnek a döntéstámogatásban?

- Megvalósul az igazgatóság függetlensége a compliance vezetôktốl? Megfelelő mennyiségú és minőségú információt kap az igazgatóság az önálló ítéletalkotáshoz? A megfelelő tudással, attitúddel rendelkező személyek felügyelik a compliance szervezet munkáját? Milyen rendszerességgel találkoznak? Túlságosan igénybe veszi a vezetók idejét és figyelmét a compliance menedzsment (humántôke-költség)?

- Hogyan mutatható be a vezetốk elkötelezettsége a szabályszerú múködés iránt?

- Milyen ár-érték aránnyal múködik a compliance menedzsment az adott szervezetnél? Milyen alternatívák hozhatnak jobb eredményt (pl. egyszerúsítés, külsố szolgáltatók bevonása, meglévő mérések felhasználása, átalakítása)? Arányosak a compliance erófeszítések a létrehozott értékekkel? Elegendô emberi erôforrás áll rendelkezésre, hogy a compliance tevékenységeket dokumentálja, elemezze, értékelje? Hogyan méri a szervezet a compliance célú pénzügyi ráfordítások megtérülését?

- Milyen szinten valósul meg az integráció a felelôs vállalatirányítás, a belsố ellenốrzés, a kockázat- és a compliance menedzsment között?

- Hogyan javítható tovább a szervezet compliance terve, tevékenységei, teljesítménye?

\section{Következtetések és megjegyzések}

A befektetốk, szabályozó hatóságok, a közvélemény és egyéb külső érdekelt feleknek az átlátható múködéshez kapcsolódó igényeire, elvárásaira adott újszerú válasz a compliance menedzsment. A 80-as évek minőségmenedzsment-forradalmához hasonlóan most is az érintett felek elvárásai, az üzleti környezet jelentik a motivációt. Számtalan botrányos vagy jogsértő eset kapott nyilvánosságot, melyek megrendítették a belső folyamatokba vetett általános bizalmat. A bizalom helyreállításának egyik módja, ha a vállalat beszámo- lókon keresztül lehetővé teszi a bepillantást a belső folyamatokba és a compliance területen elért eredményeket (vagy hiányosságokat) nyilvánosságra hozza.

Az amerikai példa nagyon erôs hatással van az üzleti életben arra, hogy milyen egy elfogadhatóan hatékony, ésszerúen múködố compliance funkció. $\mathrm{Az}$ FSGO-iránymutatások, a SOX-törvény és a COSOkeretrendszer ismerete minimum követelménynek tekinthetô egy compliance funkció felépítésénél. Természetesen minden szervezet magára szabva használhatja az ezekben leírtakat, a szakmai profilhoz kapcsolódóan más szabványok is relevánsak lehetnek. A tervezés során célszerú kijelölni a compliance tevékenységek határait (belső ellenőrzés, kockázatkezelés, egyéb funkcióktól való szétválasztás), szem elôtt tartva a compliance menedzsment fenntarthatóságának és eredményességének korlátait:

- a célok helytelen meghatározása,

- elfogult, téves, gondatlan döntéshozatal,

- a vezetés felülírja a belső ellenórzést, egyéb hatáskör-túllépés,

- az ellenőrzés, audit kijátszása,

- a szervezet hatókörén túlmutató külsố események (pl. a tőzsde összeomlása),

- szúkös erőforrások.

A compliance értékelés elsố szempontja tehát a tervezési hatékonyság. A második bemutatott szempont a múködési hatékonyság. Fontos újra megemlíteni, hogy a compliance menedzsment összetett és szervezetspecifikus tevékenységek sorozata, ezért értékelésének is illeszkednie kell a szervezet sajátosságaihoz. A compliance értékelés harmadik szempontja szerint az elért eredményeket, a compliance menedzsment szervezetre gyakorolt hatását érdemes vizsgálni. Ebben segíthet a tervezés során választott szabvány vagy egy jó mérési módszertan. Minden értékelés talál hibákat, hiányosságokat és azonosít fejlesztési irányokat. Az önszabályozásban előrehaladva egyre nagyobb súlyt kap a saját hibákból való tanulás, a nagyobb önismeret versenyelónyöket hozhat a vállalat számára.

Jelenleg a vállalati compliance tevékenységek értékeléséhez nem áll rendelkezésre kidolgozott módszertan magyar nyelven. A Deloitte és a Belső Ellenőrök Magyarországi Szervezetének idei közös felmérése a legfóbb akadályok között az erőforrások - mind az anyagi, mind a kompetens emberi eróforrások - szúkösségét és az audit IT-támogatásának elmaradottságát azonosította.

A compliance menedzsment területén számos innováció és kutatás várható a jövớben. Az egyik lehetséges 
fejlesztési terület éppen az audit, a mérés és értékelés. Másrészrôl érdekes lenne megvizsgálni, hogy a felelős vállalatirányítás hogyan hat vissza a jogalkotóra. A szabályszerú múködésre való törekvés számos kérdést, nehézséget hozhat a felszínre, aminek következtében a szabályok követésén vagy megszegésén túl más alternatívák előtérbe kerülhetnek. A szabályok megkérdőjelezése, megújítása vagy változtatása egy lehetséges irány, miként a compliance menedzsment kiindulópontja, úgy a perspektívája is a vállalati felelősségvállalás és a társadalmi párbeszéd.

\section{Felhasznált irodalom}

Benedek P. (2012): Compliance Management - a New Response to Legal and Business Challenges. Acta Polytechnica Hungarica, Vol. 9, No. 3: 135-148. o.

COSO (2013): Internal Control - Integrated Framework, Executive Summary, http://www.coso.org/documents/ coso\%202013\%20icfr\%20executive_summary.pdf, 2013/10/19

Deloitte (2013): Felmérés a belsô ellenôrzés és a compliance helyzetéról 2013, Deloitte, http://www.deloitte.com/ assets/Dcom-Hungary/Local\%20Assets/Documents/ Surveys/IASurvey_HU_2013_FINAL.pdf, 2013/10/19

Health Care Compliance Association (2003): Evaulating and improving a compliance program, Health Care Compliance Association, 2003, http://www.ucdmc. ucdavis.edu/compliance/pdf/evalimp.pdf, 2013/10/19

Lipton, M. - Neff, D.A. - Brownstein, A.R. - Rosenblum, S.A. - Emmerich, A.O. - Niles, S.V. - Mathew, S.J. - Walker, B.M. - von Bismark, P. (2008): Risk Management and the Board of Directors; Wachtell, Lipton, Rosen, Katz, November 2008, http://blogs.law.harvard.edu/corpgov/ files/2008/11/risk-management-and-the-board-ofdirectors.pdf, 7-13 o., 2013/10/19

Merétey-Vida Zs. (2007): Belső kontrollrendszer különböző felfogások tükrében, BGF Szakmai Füzetek, 22. szám, 90-98. o.

Nemzetgazdasági Minisztérium (2009): Rendszerellenórzési módszertan, Nemzetgazdasági Minisztérium (2009) http://www.kormany.hu/download/5/9f/10000/ Rendszerellen\%C5\%91rz\%C3\%A9si\%20m\%C3\%B3d szertan.doc, 2013/10/19

OCEG (2013): Guide-GRCMetrics \& Measurement, OCEG, http://www.oceg.org/resources/guide-grc-metricsmeasurement/, 2013/10/19

OECD (2013): Principles of Corporate Governance, 2004, http://www.oecd.org/dataoecd/32/18/31557724.pdf, 2013/09/30

Parker, C. (2002): Is there a reliable way to evaluate organisational compliance programs?http://www.aic. gov.au/events/aic\%20upcoming\%20events/2002/ / media/conferences/regulation/parker.ashx, 2013/10/19

Risk and Compliance Case Studies, Resources Global Professionals, http://www.resourcesglobal.com/index. php?page $=03$ CS10\&lang=USEN, 2013/10/19

Silverman, M. (2008): Compliance management for Public, Private, and Nonprofit Organizations. London: McGraw-Hill

Tarantino, A. (2008): Governance, Risk and Compliance Handbook. Chichester: John Wiley \& Sons

University of California (2013): Understanding Internal Controls, University of California, http://www-bfs.ucsd. edu/blink/ocbfs/acc/UnderstandIC.pdf, 2013/10/19 